\title{
Pierre Chabal
}

Université Le Havre Normandie, France, Le Havre, e-mail: pierrechabal@yahoo.fr

\section{THE CONCENTRIC DYNAMIC OF THE 'SHANGHAI COOPERATION' FOR IRAN AND THE ISSUE OF 'PAN-ASIA-CENTRISM'}

This article is devoted to the study of the conceptual relationship between the concepts of "regional axis" between neighboring states and the concept of "Pan-Asia-centrism". On the example of Iran's foreign policy, these concepts and the possibilities of its foreign policy choice are considered taking into account the activities of regional groups. Two approaches to understanding the concept of "Pan-Asiacentrism" are considered. Based on the approach of prof. J. Ibrashev to the understanding of "Pan-Asiacentrism", the article analyzes three dimensions of the SCO, three concentric circles around the SCO. The first circle includes the closest dimension, neighbors on a territorial basis. The second circle involves exploring an expanded understanding of "neighbors." The third circle is an intercontinental dimension.

In Western political thought, reasoning is often held in terms of alienation or isolation. This is not suitable for understanding the dynamics of the development of non-Western countries in the 21 st century. Around Central Asia, a broad forum is being formed with a concentric inclusion of the countries of East Asia, West Asia, and South Asia. This is a very important trend after the end of the Cold War. The article makes an attempt to consider a hypothetical analysis of the consequences of the development of this trend, to offer a number of possible scenarios and understand what the trend of the SCO expansion is.

Key words: International System, Foreign Policy of Iran, Neighbourhood policy, New regionalism, Merging of diplomatic interests, "Co-sovereignisation".

\section{Пьер Шабаль}

Гавр Университеті, Франция, Гавр, e-mail: pierrechabal@yahoo.fr

\section{Иран үшін «Шанхай Ынтымақтастықтың» шоғырландырма динамикасы және «Пан-Азия-центризм» мәсекесі}

Бұл мақала көрші мемлекеттер арасындағы «аймақтық дің» ұғымы мен «Пан-Азия-центризм» ұғымдарының концептуалды байланысын зерттеуге арналған. Иранның сыртқы саясаты мысалында, бұл ұғымдар және оның сыртқы саясатты таңдау мүмкіндіктері аймақтық топтардың қызметін ескере отырып қарастырылады. «Пан-Азия-центризм» түсінігін ғылыми деңгейде талдаудың екі тәсілі қарастырыла отырып, негізінен профессор Ж. Ибрашевтың көзқарасына негізделген. «Пан-Азия-центризм» түсінігіне орай, мақалада ШЫҰ-ның үш өлшемі, ШЫҰ-дағы үш концентрациялық, шеңбер талданады. Бірінші шеңберге ең жақын өлшем, аумақтық негіздегі көршілер кіреді. Екінші шеңберге «көршілер» туралы кеңейтілген түсініктерді зерттеуді қамтиды. Үшінші шеңбер - бұл құрлықаралық өлшем.

Батыстық саяси көзқарастарда пайымдау көбінесе иелік ету немесе оқшаулану тұрғысынан қарастырылады. Бұл XXI ғасырдағы батыс емес елдердің даму динамикасын түсіну үшін жарамсыз. Орталық Азияның айналасында Шығыс Азия, Батыс Азия және Оңтүстік Азия елдерін әр түрлі орталықтандыру үлерісіне біріктірумен кең форум құрылып жатыр. Бұл қырғи қабақ соғыстың аяқталғаннан кейінгі маңызды бағыт. Мақала осы тенденцияның даму салдарын гипотетикалық та^дауды қарастыруға, бірқатар мүмкін сценарийлерді ұсынуға және ШЫҰ кеңею трендінің не екенін түсінуге тырысады.

Түйін сөздер: Халықаралық жүйе, Иранның сыртқы саясаты, көршілестік саясаты, жаңа регионализм, Аипломатиялық мүАлелерін біріктіру, "Қатар өмір сүру".

Пьер Шабаль

Университет Гавра, Франция, г. Гавр, e-mail: pierrechabal@yahoo.fr

\section{Концентрическая динамика «Шанхайского Сотрудничества» дяя Ирана и вопрос «Пан-Азия-центризма»}

Аанная статья посвящена изучению концептуальной связи между понятиями «региональная ось» межАу сосеАними государствами и концепцией «Пан-Азия-центризма». На примере внешней 
The concentric dynamic of the 'Shanghai cooperation' for iran and the issue of 'Pan-Asia-centrism'

политики Ирана рассмотрены эти концепции и возможности его внешнеполитического выбора с учетом деятельности региональных группировок. Рассмотрены два подхода к пониманию концепции «Пан-Азия-центризма». На основе подхода проф. Ж. Ибрашева к пониманию «ПанАзия-центризма» в статье проводится анализ трех измерений ШОС, трех концентрических кругов вокруг ШОС. Первый круг вк^ючает в себя ближайшее измерение, соседей по территориальному принципу. Второй круг предусматривает изучение расширенного понимания «соседей». Третий круг преАставляет собой межконтинентальное измерение.

В западной политической мысли зачастую рассуждения проводятся с точки зрения отчужАения или изоляции. Это не поАходит Аля понимания Аинамики развития незапаАных стран в XXI веке. Вокруг Центральной Азии образуется широкий форум с концентрическим включением стран Восточной Азии, ЗапаАной Азии, Южной Азии. Это является весьма важной тенденцией после окончания «холодной войны». В статье слелана попытка рассмотреть некий гипотетический анализ послеАствий развития этой тенденции, преАложить ряА возможных сценариев и понять, что же из себя представляет тенденция расширения ШОС.

Ключевые слова: международная система, внешняя политика Ирана, политика соседства, новый регионализм, слияние дипломатических интересов, «Сосуществование».

\section{Introduction}

This text explores at the same time a debate over the concept of a regional axis and the applied reality of the foreign policy choices of a country, here Iran, as well as of regional groupings. The conceptual link between $\mathrm{i} /$ the notion of a "regional axis" among neighbours launching a novel form of common interaction and ii/ J. Ibrachev's concept of a "Pan-Asia Centrism" (J. Ibrashev 2006), first suggested in 2006, is simple enough to grasp. It concerns the regional version of the concept of Heartland as "pivot" originally provided by H. Mackinder in 1904 and, since then, widely used, disputed, updated.

There exist, however, two ways of understanding the concept of "Pan Asia Centrism". Either i/ the words "Pan ASIA CENTRISM" suggest that Asia is at the centre everywhere in the world and, thus, Asia is at the centre of Eurasia, and Eurasia is at the centre of the world. That is, in a reverse pattern from Mackinder's, Central Asia dominates the world. Or ii/ in another way to envisage things, the words "PAN ASIA centrism" mean something else: here Asia is "united" and becomes a centre among the several centres of a multi-polar world. Central Asia, thus, is "animated" - to use Ratzel's phrase - by a more realistic and credible project, that of a legitimate pole (M. Geoffrey J. and P.E. James, 1993).

This second manner of understanding $\mathrm{J}$. Ibrachev's concept of "Pan Asia Centrism" inspires the present analysis applied to "SCO-centrism" and to the concept of a regional "axis", through three concentric circles around the SCO. These form the three sections of the paper. We thus look in succession at a first circle, that of the immediate neighbourhood dimension (I); at a second circle, that of the expanded "good neighbours" dimension (II); and at a third circle, that of the strategic inter-continental dimension (III).

\section{I - First circle: the immediate neighbourhood dimension}

That is, as we suggest, the various degrees of partnerships between SCO "member-states" and "observers" and/or "dialogue partners". In this paper, we will consider that the formal (legal and procedural) distinction between SCO "members" (Декларация, 2001), "observers" (Решение ШОС, 2004) and "partners" (Решение ШОС, 2008) is less relevant than the geostrategic meaningfulness of their common SCO "affiliation". Iran, being one of the early observers (Иран получил статус наблюдателя, 2005) and very early applicants (2006) to the SCO, qualifies very well for being the focus of this paper on "the concentric dynamic" of the SCO within the "New Asia". Two reasons at least support this view and more generally deserve "western" attention.

- On the one hand, one common mistake made by the western observers and negotiators of a nuclear "deal" (that is neither a deal - but a misperception of the post-cold-war dynamics - nor a negotiation on nuclear issues - but an imposition of power-relations over the Middle-eastern geopolitical space) is to consider that progress in a nuclear deal is an indicator of a positive impact of the West. It is in fact a disruptive factor in the "asianiation" dynamic under the influence of "the New Asia" and of China, or - to be more exact - under the combined Chinese-RussianCentralasian influence. For instance, it is notably a confirmation of this view that recent meetings have been taken place in Astana, Kazakhstan, and not in the usual Geneva or other western capital as was the case as so often in the past when it came to "negotiating" international affairs. 
- On the other hand, the factual evidence is one of the natural focus of Iran's foreign policy having shifted to the East, not by sheer chance but as a consequence of contemporary international dynamics. This, too, is under-looked by the West. Since this paper was presented at a conference held in Iran, there was in Tehran no need to detail a few points of reasoning. These however ought to be mentioned here. i/ While Iran's willingness to join the Gulf Cooperation Council (GCC) was turned down by several times GCC members (Vakil Sanam, 2018, 19), this led to the creation by Iran of the Economic Cooperation Organisation (ECO, 1984). ii/ While the western attitude towards Iran was "out of its constructive phase" more or less even since 1979 (until the Joint Comprehensive Plan of Action - JCPA, Geneva, 2015), soon to be jeopardised by the change of US leadership attitude after 2016, this led to Iran's foreign policy being confirmed as an insertion into the Shanghai Cooperation Organisation (SCO) circles of influence to the point of becoming one of China's favourites for full membership.

So, all taken in consideration, whether Iran, a neighbour to one SCO-member, one SCO-observer (Решение ШОС, 2005), three SCO-partners and one SCO-guest, becomes the $9^{\text {th }}$ member of the SCO or the $10^{\text {th }} \ldots$ (after Belarus or Afghanistan, which would make more immediate sense to go along with the Organisation's "contiguity" criterion, Belarus contiguous to Russia, Afghanistan contiguous to four member-States - but Iran contiguous still to six "affiliates") makes less difference than indeed the "detachment" of Iran from "western Eurasian" affairs, one step further than its disengagement, and its insertion into the "neo-Asian" affairs. What will be lastingly changed is nothing less than decades of post-WW-II dynamics when the Western Eurasian actors progressed in influence towards the East (OSCE, NATO, EU, ...) and will lose that influence to the East (SCO, CSTO, EAEU,...). And that is in Iran's interest, bearing in mind that, in their pursuit of international relations, as the phrase goes, States have "interests to pursue" more than "friends to entertain".

The logical conclusion of this first section is that the one surprising factor of the present times is the relevance of the relative silence of the Vienna-based International Atomic Energy Agency (IAEA). Yet, the IAEA has in the past vouched to the compliance of Iran's inspections with the requirements of the Joint Comprehensive Plan of Action (Joint Comprehensive Plan of Action, 2015). Thus, what ought to be debated is the foundation of the unilateral toughening of measures by the USA on Iran's oil exports, currency situation and macro-economic viability. This point is here of course not satisfactorily expressed by the paper's author in diplomatic terms. But as a free academic, not a diplomat, the paper's author only suggests that, intellectually speaking, a western change of policy towards more sanctions on Iran would be a contradiction in terms. To risk a provocative metaphor, it would mean for the West to severe negotiations with Iran rather than severing all links with a family cousin on account of a stubbornness of the part of the conservative family members vis-à-vis the progressive members of the family.

\section{II - Second circle: the expanded "good neigh- bours" dimension}

That is, a dynamic whereby SCO "affiliates" of all "categories" logically all look - each of them in its own way - for potential initiators to form "axes" of "collaboration". Having written, on previous occasions, on the concept of regional "axes", we feel justified to reflect here on a regional axis for "the New Asia" that would include Iran. But first, however, the very concept of a regional "axis" as suggested here should be made more specific. A regional axis can be defined as "a privileged relation among two neighbour-partners that are prepared to "turn the page of history" containing tensions or even wars, in the name of the continuous stability of their region and around which that region, with other neighbours-partners, can construe itself in a stabilising and open-ended manner" (author's definition).

This suggests analysing, together and along with the reader, which country, contiguous or not, could be Iran's "partner" to form such an "axis".

The first suggestion that comes to mind is that of the middle powers' drive toward regional cooperation and integration. We looked at this concept in Mongolia the very year (2004) when Mongolia inaugurated the category of Observers to the SCO (P. Chabal, 2005, 82-88). And bearing in mind the complementary concept of an "arc" of such middlepowers, including the cartographic line that extends from Mongolia, Kazakhstan, Turkmenistan to Iran and Turkey, we would like to share with Asian and Iranian colleagues some research issues as to which countries in Asia and Eurasian would, together with Iran, engage in such an opened and lasting form of region-building, irrespective of immediate considerations.

Bearing in mind that the reinforcing "axis" of the post-WWII European construction is that between France and Germany (Le traité de l'Élysée, 1963), 
less than twenty years after the two countries were engaged in their third open war since 1870, history suggests that no impossibility exists in forming such an "axis". The logic is to decide i/ where to anchor the region and ii/ on which scale to strengthen it.

- An Iran-China axis might surprise many a reader as unusually envisaged. This is not to suggest that China is a middle-power but to underline rather the western Eurasian direction in which - and to which - China is looking, certainly "all the way West" to Iran, or Turkey or even Syria, nay Egypt. This axis would also provide Iran with an Easternmost-reaching dimension into the continent. There needn't be more justification here of this deeply innovative rupture opened to neo-Asian decisionmakers (!)

- An Iran-Turkmenistan axis would constitute or "finalise" the southern Caspian connecting "flank" to Central and East Asia, incidentally also the main corridor for energy-transportation by land from the Caucasus to China. Such a suggestion naturally runs against the grain of two obstacles. First, does Iran intend to share with a neighbour-partner a committing, privileged bond that, over time and despite the difficulties, will become what may constitute a pillar or Iranian strategic interests? Second, is Turkmenistan to alter its restricted-open-door policy since December 1991, immediately after independence, slightly re-oriented since December 2006, following a change of President, and confirm that the country can bi-lateralise its relations "beyond Russia" and form with Iran a "couple" that will be conducive to multi-lateralising relations in Eurasia?

- An Iran-Kazakhstan axis, "on either side" of Turkmenistan and of the Caspian Sea, would be the most innovative among i/ the Iranian "gate" between the Turkic and the European worlds and ii/ the Kazakhstani "gate" between East-Asia and Russia (only Mongolia can be the alternative connection between China and Russia). Such an axis would provide the two partners with a "multiplicator" of their power-base as i/ Iran would no longer be on the "periphery" of Western interests but at its centre and in the heart of the new Eurasian strategies; and as ii/ Kazakhstan would benefit from an ultimate diversification from Chinese-Russian dimensions and from an Asia-Asian "centering", precisely the opening towards which Astana has been working since 1992 .

In all, this brief section II opens an "axial" discussion of countries. Suc a discussion must be completed with the scenario of an axis among organisations, not necessarily only among two countries.

\section{III - Third circle: the strategic inter-continen- tal dimension}

That is, as we have suggested, for the dynamic of the SCO-at-large in the central parts of the Eurasian continent, here, in Western Eurasia, advancing the view that leading organisations would form with the SCO such a privileged an inter-organisational kind of a transcontinental innovation.

Among these suggestive innovations, an organisation such as the Economic Cooperation Organisation (Agreement on Legal Status of the ECO, 1984) founded by Iran over twenty-five years ago, in 1984, is a case in point. The political and economic nature of this intergovernmental organisation corresponds rather well to that of other Eurasian organisations examined below. Founded by Iran, Pakistan and Turkey, its membership, under-looked in the West, comprises all relevant countries of the region, and its aim is to establish a single market, a similar and compatible aim with that of most other organisations in the region. Iran is in this sense as well equipped as most countries in the "new Asia" to play a significant role in this inter-Organisations game.

- Notably, the ECO membership corresponds by and large to that of these other regional organisations, in particular the Shanghai Cooperation Organisation. The ECO members comprise two SCO "dialogue partners" (Turkey, Azerbaijan), two SCO "observers" (Afghanistan, Iran), five SCO "member-States" (Kazakhstan, Kyrgyzstan, Pakistan, Tajikistan, Uzbekistan) and one SCO "guest attendant" (Turkmenistan), in total ten SCO "affiliates" out of nineteen. Thus, an axis between the ECO and the SCO is a logical one and should be taken seriously by non-regional observers. The rationale here is simple. If in 2007 an organic rapprochement was suggested between the secretariats of the SCO and that of the CSTO, why not envisage a similar dynamic between the SCO and the ECO, bringing together also the dynamics of East Asia (China) and West Asia (Iran)?

- Alternatively, an axis between the ECO and the Eurasian Economic Union (Договор о ЕАЭС, 2015) could be mentioned. Indeed, the EAEU comprises a number of countries involved in the ECO, namely two important regional actors: Kazakhstan and Kyrgyzstan. And EAEU members also include Armenia, Belarus and Russia. This spatial scope suggests, incidentally, that Iran could join the EAEU as part of the enhanced inclusion of Iran into Asian co-operations looking to the East. Here the main aims and ambitions of the two organisations, 
the ECO and the EAEU, being similar, the complementarity is obviously one that would lead to the economic integration of an even much larger part of the continent.

- Finally, an inter-organisational axis between the ECO and the Collective Security Treaty Organisation could be envisaged, this time bringing together the economic focus of the ECO and the military focus of the CSTO. Members of the CSTO are Armenia, Belarus, Kazakhstan, Kyrgyzstan, Russia, Tajikistan, since Uzbekistan (1991-1998, then 20052012) pulled out in 2012. And so, the ECO-CSTO "overlap" comprises the following countries: Kazakhstan, Kyrgyzstan and Tajikistan, members of both organisations. This suggests that an "axis" between these two organisations and the subsequent admission of more countries into each organisation from the partner organisation, would make the "axis" capable of overseeing both the security and material stabilities of the region.

In total, an interesting fact should be pointed out. Differently from most if not all regional and global organisations, the Iran-created ECO has spread its institutions over several countries, namely basing its Secretariat and Cultural Department (SCD) in Iran, establishing its Economic Bureau (EB) in Turkey and locating its Scientific Bureau (SB) in Pakistan. This makes the ECO not only a very modern form of strategic institutional set-up but also an organisation capable of "functioning" and "thinking" across the continent.

\section{Conclusion}

In conclusion, the simple but main thrust of this paper is not policy-oriented. Academics ought to refrain from believing that they can advise governments or diplomats. The views expressed are simply a form of "thinking aloud" in the hope of sharing (with other academics) a view as to these dynamics and to some extent hypothetical forms of analysis of a Weberian inspiration. The well-established Weberian "What If?" approach consists of suggesting a number of possible scenarios, as ideal-typical constructs, and then analyse what their consequences would be.

Against the main grain of Western thought when it comes to non-Western realities, the reasoning in terms of exclusion or isolation, is not appropriate for understanding $21^{\text {st }}$ century dynamics. The "New Asia" operates largely, by contrast, along inclusive lines and the 2018 conference held in Tehran, capital of ancient Persia, where this paper was originally presented, came at a welcome point to appraise the significance of the impact of the "extended" on the $21^{\text {st }}$ century. Whether through formal extension (enlargement of membership) or by the merging of diplomatic interests, in a sort of "juxta-sovereignisation" (beyond mere co-operation by co-sovereignisation but not aiming for supra-sovereignisation), what makes more and more sense is the inclusion of sub-regions into a common dynamic.

The concentric inclusion of East Asia, West Asia and now South Asia into an encompassing forum around the New Central Asia is, to date, the most striking innovation of the post-cold-war. An innovation of which Iran is a cornerstone, whether the West understands this or not. And of which several other "pan-Asia" countries are part and parcel, again whether the West understands it or not.

\section{References}

Chabal P. (2005) Middle powers' drive towards regional cooperation: the case of Northeast Asia, in Bulletin of the Kazakh National University, Series in International relations \& law, №4 (20), p. 82-88.

CNTD (2019) Dogovor o Evraziyskom economicheskom souze [Eurasian Economic Union Treaty] Retrieved from http:// docs.cntd.ru/document/420205962 (In Russian)

Database legislation of CIS countries (2004) Reshenie ShOS Sovet glav gosudarstv ot 17.06.2004 №9 O polojenii o statuse nabludatelya pri ShOC. [Decision of the Shanghai Cooperation Organization Council of Heads of State dated June 17, 2004 No. 9 On the Regulation on the Observer Status of the Shanghai Cooperation Organization] Retrieved from https://base.spinform.ru/ show_doc.fwx?rgn=6909 (In Russian)

Database legislation of CIS countries (2005) Peshenie ShOS Soveta glav gosudarstv-thlenov ShOC o predostavlenii Iranu statusa nabludatelya pri ShOC. [Decision of the Council of Heads of State of the Shanghai Cooperation Organization On granting observer status to the Islamic Republic of Iran at the SCO] Retrieved from https://base.spinform.ru/show_doc.fwx?rgn=8213 (In Russian)

ECO (2017) Agreement on Legal Status of the ECO, National Representatives and International Staff . Retrieved from http:// eco.int/ (In Russian)

Herodote.net (1963) Le traité de l'Élysée. [The Élysée Treaty] Retrieved from https://www.herodote.net/22_janvier_1963-evenement-19630122.php (In French) 
Ibrashev J.U. (2006) Manifest panaziyacentrizma. [Manifesto of Panaziacentrism] - Almaty. (In Russian)

Ibrashev J.U. (2006) Osmislenie panaziyacentrizma // Bezopasnost cherez sotrudnithestvo: teoriya, metodologiya i praktika. [Understanding panaziacentrism // Security through cooperation: theory, methodology and practice.] - Almaty. (In Russian)

Ibrashev J.U. (2006) Vozmojen li panaziyacentrizm // Integratsionnye vozmojnosti stran Centralnoy Azii: opit Evropeyskogo souza. [Is panazia-centrism possible? // Integration Capabilities of Central Asian Countries: European Union Experience.] - Almaty, p.6-9 (In Russian)

Iran.ru (2005) Iran poluchil status nabludatelya pri ShOC, [Iran received observer status at the Shanghai Cooperation Organization] Retrieved from https://www.iran.ru/news/politics/30620/Iran_poluchil_status_nablyudatelya_pri_Shanhayskoy_organizacii_sotrudnichestva (In Russian)

Martin J. \& Preston E. (1993) All Possible Worlds. New York, John Wiley and Sons Retrieved from https://www.goodreads. com/book/show/2290025.

See Vakil Sanam (2018) "Iran and the GCC: Hedging, Pragmatism and Opportunism", Research Paper, the Chatham House RIIS, the Middle East and North Africa Programme, $19 \mathrm{p}$.

Europarliament (2015) The Joint Comprehensive Plan of Action is an agreement on the Iranian nuclear programme signed in Vienna on 14 July 2015 by Iran, the five permanent members of the UN Security council and the European Union. Retrieved from https://www.europarl.europa.eu/cmsdata/122460/full-text-of-the-iran-nuclear-deal.pdf

Zakon,kz (2008) Reshenie ShOS Soveta glav gosudarstv ot 28.08.2008 № 1 ob utverjdenii Polojeniya o statuse partnera po dialogu ShOC. Dushanbe. [Decision of the Council of Heads of State of the Shanghai Cooperation Organization dated August 28, 2008 No. 1 On approval of the Regulation on the status of a dialogue partner of the Shanghai Cooperation Organization. Dushanbe] Retrieved from https://online.zakon.kz/Document/?doc_id=38435621 (In Russian)

Zakon.kz (2001) Deklaratsiya o cozdanii ShOC. [Declaration on the creation of the shOC] Retrieved from https://online.zakon. kz/Document/?doc_id=1027310(In Russian) 